\title{
PHYSIOLOGICAL EFFECTS OF HIGH TEMPERATURE STRESS IN SOME CUCURBIT PLANTS
}

\author{
Sergul Ergin ${ }^{1, *}$, Cigdem Aydogan ${ }^{1}$, Ece Turhan ${ }^{1}$ \\ ${ }^{1}$ Eskisehir Osmangazi University, Faculty of Agriculture, Department of Agricultural Biotechnology, \\ Eskişehir, Turkey
}

\section{Current Trends in}

\section{Natural Sciences}

\begin{abstract}
Some cucurbit plants (Cucumis sativus L., Cucurbita pepo L., Cucumis melo L. and Citrillus lanatus L.) were used for investigating some physiological changes and protein patterns under heat stress in plants. Leaf samples were exposed tohigh temperatures as follows $35,40,45,50,55$ and $60^{\circ} \mathrm{C}$. Percentage of ion leakage, chlorophyll content, leaf relative water content $(R W C)$ and loss of turgidity, total soluble protein (TSP) content and protein profiles were determined in leaf samples kept at each temperature stage for 30 minutes. Ion leakage was increased especially 55 and $60^{\circ} \mathrm{C}$ in all cucurbits parallel to the temperature increasement. Total chlorophyll content was decreased slightly in both cucumber cultivars, zucchini, in both melon cultivars and watermelon due to high temperatures. The RWC of cucurbits was decreased on the contrary of the loss of turgidity, which was parallel to the increment of temperatures. While the TSP content in cucumber was decreased with temperature increasement, it was not changed in zucchini and watermelon. In melon cultivars TSP was not noticeably changed until $55^{\circ} \mathrm{C}$, but significantly decreased at $60^{\circ} \mathrm{C}$. When the SDS-PAGE profiles of cucurbits were examined, many protein bands were observed with sizes ranging from $6.5 \mathrm{kDa}$ to $211 \mathrm{kDa}$.
\end{abstract}

Keywords: Chlorophyll, Cucurbitaceae, heat stress, ion leakage, protein.

\section{INTRODUCTION}

Abiotic stresses such as high temperatures, water deficit and salinity, individually or associated lead to a series of morphological, physiological, biochemical and molecular changes in plants (Wang et al., 1999). High temperature is one of the major abiotic stresses that limiting plant growth and productivity (Szymanskaa et al., 2017). The average temperature over land for the period 20062015 was $1.53^{\circ} \mathrm{C}$ higher than for the period $1850-1900$, and $0.66{ }^{\circ} \mathrm{C}$ larger than the equivalent global mean temperature change. These warmer temperatures have altered the start and end of growing seasons, contributed to regional crop yield reductions (Shukla et al., 2019). Therefore, the alleviation of the harm of high temperature stress and reduction of the associated agricultural loss has recently become a topic of significant concern (Zhou et al., 2016).

Significant metabolic indication of various stresses is oxidative damage and heat stress enhances the formation of reactive oxygen species (ROS), thereby causing oxidative stress (Suzuki and Mittler, 2006; Pucciariello et al., 2012). Alterations in membranes permeability and functions and their damage by peroxidation of lipid constituents (Sharma et al., 2012) are the main effects of ROS under heat-stressed regimes (Balal et al., 2016). Plant tolerance to various environmental stress 
factors estimated based on measurement of stress-induced ion leakage from plant tissues. It has become widely accepted that the more plants are stressed, the more disintegrated cell membranes they have, which caused in increase passive efflux of ions from cytosol. This disintegration is considered to be irreversible and to lead to cell death (Levitt, 1980; Ilik et al., 2018)

Chlorophylls play an essential role in photosynthesis (Mathis and Burkey, 1989) and there is a positive correlation between chlorophyll content and photosynthesis in plants (Lin et al., 2011). High temperature stress reduces leaf chlorophyll content in plants, resulting in and ultimately affecting plant growth and yield (Zhou et al., 2016; Balal et al., 2016). Studies have shown that under high temperature stress, the chlorophyll bioaccumulation of cucumber seedling leaves is significantly inhibited, and the chlorophyll concentration is reduced (Zhou et al., 2016). As a result of decreased chlorophyll synthesis and therefore photosynthesis, plants have developed specific adaptation mechanisms to high temperature stress.

Relative water content (RWC) is an important parameter used in evaluating the adaptability of the plants to stress conditions which is closely reflecting the balance between the water in the leaf and the transpiration rate (Yamasaki and Dillenburg, 1999; Dhanda and Sethi, 2002; Liu et al., 2008).

It is reported that there was a decrease in RWC values with high temperature applications in mung beans (Kumar et al., 2011).

Plants exhibit various cellular and metabolic responses which are necessary for their survival under high temperature conditions (Guy, 1999). On the cellular and molecular level, membranes and the cytoskeleton, proteins, enzymes and RNA are the most affected. These effects include changes in the organization of cellular structures (including, changes in the organization of the organelles and the cytoskeleton), and membrane functions, accompanied by a decrease in the synthesis of normal proteins and the accelerated transcription and translation of heat shock proteins (Weis and Berry, 1988; Bray et al., 2000; Ruelland and Zachowski, 2010; Suzuki et al., 2012; Hasanuzzaman et al., 2013; Bita and Gerats, 2013). The synthesis of new proteins or the decrease in their synthesis in plants exposed to stress, and the destruction of existing proteins are shown as a defence mechanism against stress. Total soluble proteins are among the compounds that show the greatest variation under stress conditions (Turhan et al., 2015; Ergin et al., 2016).

Cucumber (Cucumis sativus L.), zucchini (Cucurbita pepo L.), melon (Cucumis melo L.) and watermelon (Citrullus lanatus) are important crop for their nutritional properties and benefits for human health, that belonging to the family of Cucurbitaceae. High temperatures can cause thermal injury by ROS production and negatively effects plant growth and, as a result, crop yield in cucurbits (Zhou et al., 2016; Palma et al., 2014; Pinero et al., 2021; Hou et al., 2016). Responses to high temperature stress are a complex response depending on the duration and severity of the stress and the plant species. Changes and responses to thermal stress induced in the plant occur at all functional levels of the organism, which are reversible at first, but may become permanent. Even if the stress condition is temporary, the plant vitality decreases according to the stress duration (Silva et al., 2018).

Understanding the response of plants to high temperatures and the adaptation mechanisms they developed is important to maintain agricultural productivity. In this way, it will be possible to obtain new cultivars that are tolerant to high temperatures. In this study, it was aimed to investigate the physiological and molecular responses of some cucurbit plants to high temperatures. 


\section{MATERIALS AND METHODS}

Leaves were collected from cucurbit plants (Cucumis sativus L. cvs. Maraton and Max 2001, Cucurbita pepo L. cv. Asma, Cucumis melo L. cvs. Miranda and Poli and Citrillus lanatus L. cv. Crimson Tide in vegetative stage. The average temperatures were measured as $22-24^{\circ} \mathrm{C}$ when the plants were grown. The controlled heat tests were applied to the leaf samples based on the method of Arora et al. (1998). For this purpose, leaves obtained from plants were collected into pyrex tubes with caps closed and placed into water bath. After a 30 -minute habituation at $30^{\circ} \mathrm{C}$, the water temperature was escalated to $35,40,45,50,55$ and $60^{\circ} \mathrm{C}$ temperatures with gradual increments every half an hour.

For ion leakage measurements leaf discs, a diameter of $1.5 \mathrm{~cm}$, were taken from leaves then they were rinsed deionized water and placed in tubes containing $15 \mathrm{~mL}$ of distilled water was added. After samples were shaken at $100 \mathrm{rpm}$ at room temperature for 4 hours, the amount of ion leakage was measured $\left(\mathrm{EC}_{1}\right)$ with an EC meter (Mettler Toledo, SevenEasy S30, Colombus Ohio, USA). The tubes were autoclaved at $121^{\circ} \mathrm{C}$ for 15 minutes. Finally, total electrical conductivity $\left(\mathrm{EC}_{2}\right)$ was measured and ion leakage was calculated using the following equation: Ion leakage $(\%)=\left(\mathrm{EC}_{1} / \mathrm{EC}_{2}\right)$ $\times 100$ (Arora et al., 1998)

Total chlorophyll content was determined using methods developed by Moran and Porath (1980). Three leaf discs of $1 \mathrm{~cm}$ diameter were taken from the fully expanded leaves of each treatment and soaked in $5 \mathrm{~mL}$ of dimethylformamide (DMF) for $72 \mathrm{~h}$ at $4^{\circ} \mathrm{C}$ (in the dark). The absorbance was read at $652 \mathrm{~nm}$ in spectrophotometer to measure chlorophyll content, which was calculated as $\mathrm{mg} \mathrm{g}^{-}$ ${ }^{1} \mathrm{FW}$.

Leaf RWC (\%) and loss of turgidity were measured using the methods of Barrs and Weatherley (1962). Leaf discs of $1 \mathrm{~cm}$ diameter were cut from leaves of each of the three plants (replicates) per treatment. First, the fresh weight was recorded, and then samples were placed in a petri dish of distilled water for $4 \mathrm{~h}$. After blotting the leaf surface with paper, turgid weights were recorded. Then, leaf samples were placed in an incubator at $70^{\circ} \mathrm{C}$ for $24 \mathrm{~h}$, to determine the dry weight. Leaf RWC and loss of turgidity were measured as fallow; RWC $(\%)=[($ fresh weight-dry weight $) /$ (turgid weight-dry weight $)] \times 100$, loss of turgidity $(\%)=[$ (turgid weight- fresh weight $) /$ turgid weight $] \times$ 100.

Total soluble proteins (TSPs) were extracted from leaf tissues using the methods described by Shen et al. (2003). Leaf tissues $(0.25 \mathrm{~g})$ were homogenized at $4^{\circ} \mathrm{C}$ in extraction buffer $[25 \mathrm{mM}$ Tris base, $275 \mathrm{mM}$ sucrose, $2 \mathrm{mM}$ ethylenediaminetetraaceticacid (EDTA), $10 \mathrm{mM}$ 1,4dithiothreitol (DTT), $0.5 \mathrm{mM}$ phenylmethylsulfonylfluoride (PMSF) and $1 \%$ polyvinylpyrolidone (PVP), pH 7.8]. The homogenates were centrifugated at $10.000 \mathrm{rpm}$ for $10 \mathrm{~min}$ at $4^{\circ} \mathrm{C}$. TSP content of supernatant was measured with the Bradford assay (Bradford, 1976). Equal amounts of total protein (10 $\mu \mathrm{g})$ were loaded into the wells and separated by sodium dodecyl sulphate polyacrylamide gel electrophoresis (SDS-PAGE) and the gels were visualized via Coomassie stain (Arora et al., 1992).

The experiment was arranged in a randomized block design with three replications. The data were analyzed using SPSS 20.0, and mean separation was calculated with a Duncan test, where $p<0.05$ was considered significant.

\section{RESULTS AND DISCUSSIONS}

In general, ion leakages of cucurbit plants were increased with the heat stress (Figure 1 and Table 1). The increment of ion leakage was significant especially at 55 and $60^{\circ} \mathrm{C}$ in all cucurbit species. In cucumber, the increment of ion leakage reached about $80 \%$ at $60^{\circ} \mathrm{C}$ in both cultivars. Ion leakage of 


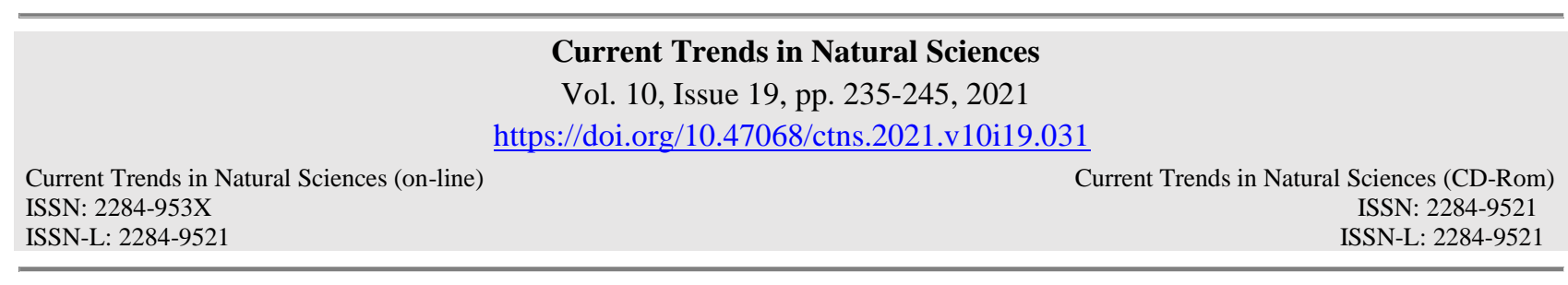

cv. Max 2001 was higher than in cv. Maraton almost in all applications. It has been determined that ion leakage was increased in parallel with high temperatures in zucchini. While the ion leakage value was determined $28.6 \%$ in control plants, the highest value was obtained from at $60^{\circ} \mathrm{C}$ (83.6\%). In melon plants, while the ion leakage of cv. Miranda was increased with high temperature applications, it was significantly increased at $55^{\circ} \mathrm{C}$ and $60^{\circ} \mathrm{C}$ after slightly increasing between $35^{\circ} \mathrm{C}$ and $50^{\circ} \mathrm{C}$ in $\mathrm{cv}$. Poli. Ion leakage of cv. Miranda was higher than cv. Poli in all temperatures. Ion leakage of watermelon plants was increased significantly after at $45^{\circ} \mathrm{C}$ and it was reached the maximum $(71.9 \%)$ at $60^{\circ} \mathrm{C}$.

Ion leakage can be used as an index for screening plants against heat and drought stress (Deshmukh et al., 1991). Membrane disruption may alter water, ion and organic solute movement, photosynthesis and respiration (Christiansen, 1978). Similar to our results it has been reported that, with increase in temperature there was a proportional increase in ion leakage in many plants (Almeselmani et al., 2006; Correia et al., 2014).
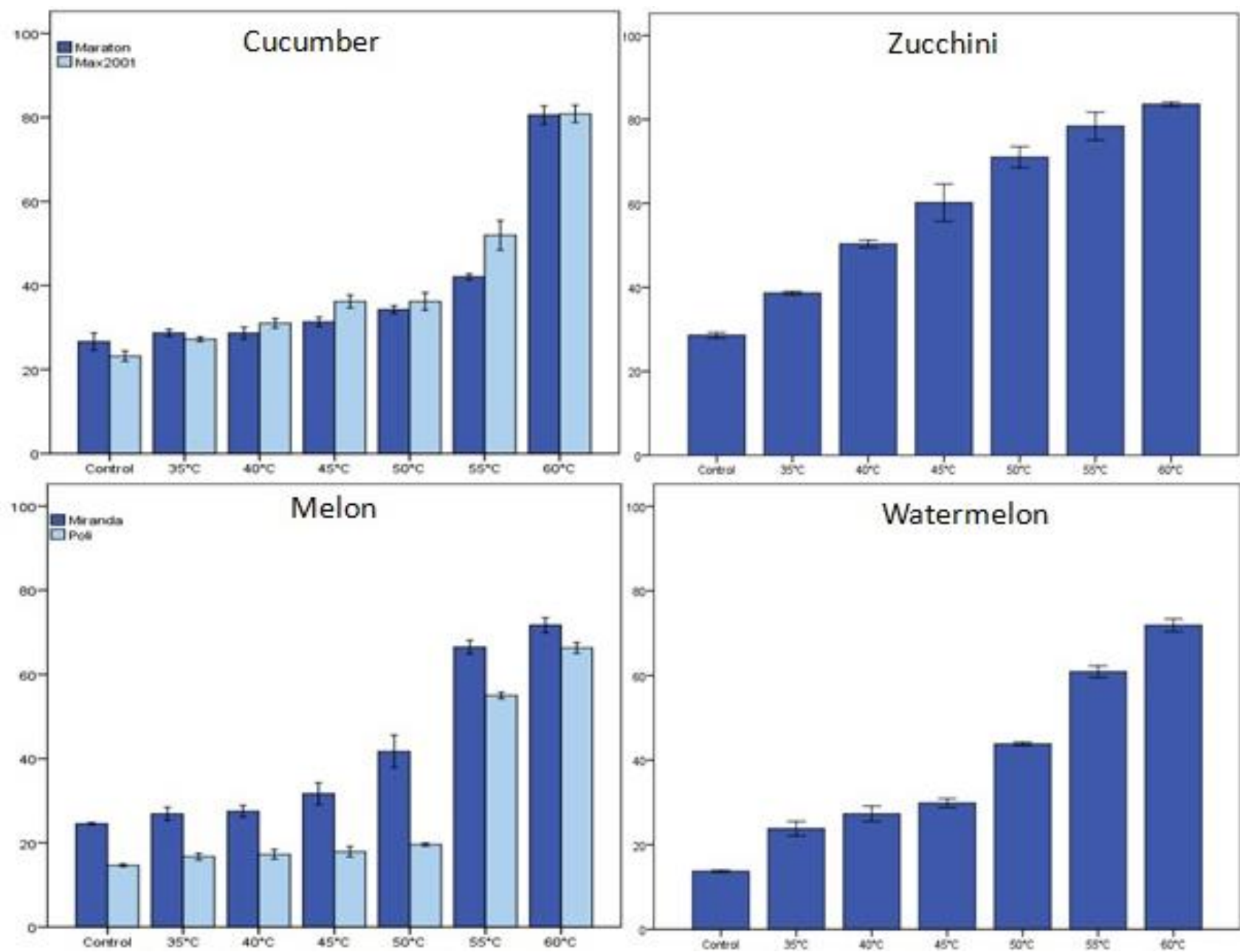

Figure 1. Effects of high temperature stress on ion leakage (\%) of cucurbit plants. Vertical bars indicate \pm S.E.

Effects of high temperature stress on total chlorophyll content of cucurbit plants was shown in Figure 2. Generally, leaf chlorophyll content of cucurbit plants was decreased following high temperature treatment. The highest $\left(5.8 \mathrm{mg} \mathrm{g}^{-1} \mathrm{FW}\right)$ and the lowest $\left(4.2 \mathrm{mg} \mathrm{g}^{-1} \mathrm{FW}\right)$ chlorophyll 


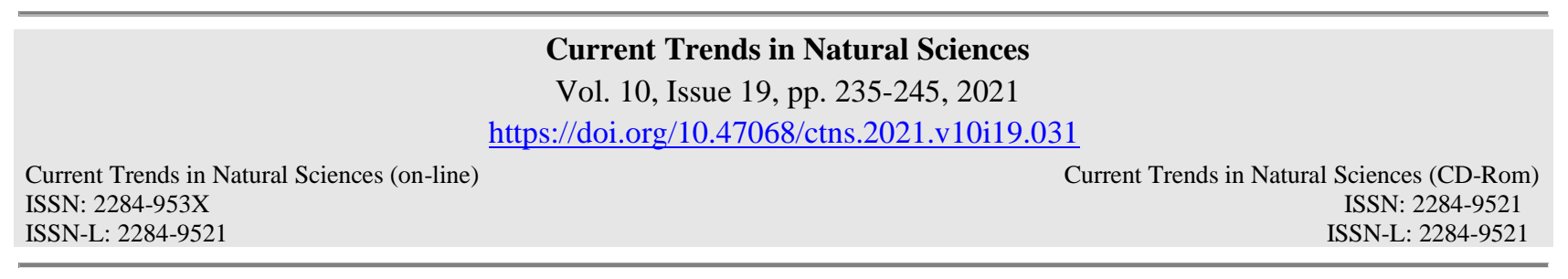

content in cucumber was obtained from cv. Max 2001 at control and $60^{\circ} \mathrm{C}$ respectively (Table1). Chlorophyll content of cv. Max 2001 was higher than in cv. Maraton in all temperatures except at $60^{\circ} \mathrm{C}$. The amount of chlorophyll was slightly decreased due to high temperatures in zucchini. In melon plants, while the leaf chlorophyll content of cv. Miranda was not changed between control and at $40^{\circ} \mathrm{C}$, it was decreased at other temperatures. The highest chlorophyll content $\left(4.9 \mathrm{mg} \mathrm{g}^{-1}\right.$ FW) was obtained from control plants, while the lowest content $\left(2.9 \mathrm{mg} \mathrm{g}^{-1} \mathrm{FW}\right)$ was obtained from $60^{\circ} \mathrm{C}$ application in cv. Poli. In terms of chlorophyll content, a similar situation was observed in watermelon as in zucchini.

Chlorophyll content provides valuable information about physiological status of plants, and can directly determine photosynthetic potential and primary production (Gitelson and Merzlyak, 2003).

High temperature stress leads to impairment of chlorophyll biosynthesis in plastids (Dutta et al., 2009). Lesser accumulation of chlorophyll in high temperature stressed plants may be attributed to impaired chlorophyll synthesis or its accelerated degradation or a combination of both (Efeoglu and Terzioglu, 2009; Mathur et al., 2014). A number of reports indicated that plants exposed to high temperature stress show reduced chlorophyll biosynthesis in wheat (Efeoglu and Terzioglu, 2009;) in cucumber (Balal et al., 2016; Zhou et al., 2016), and watermelon (Hou et al., 2016) which supports our findings.
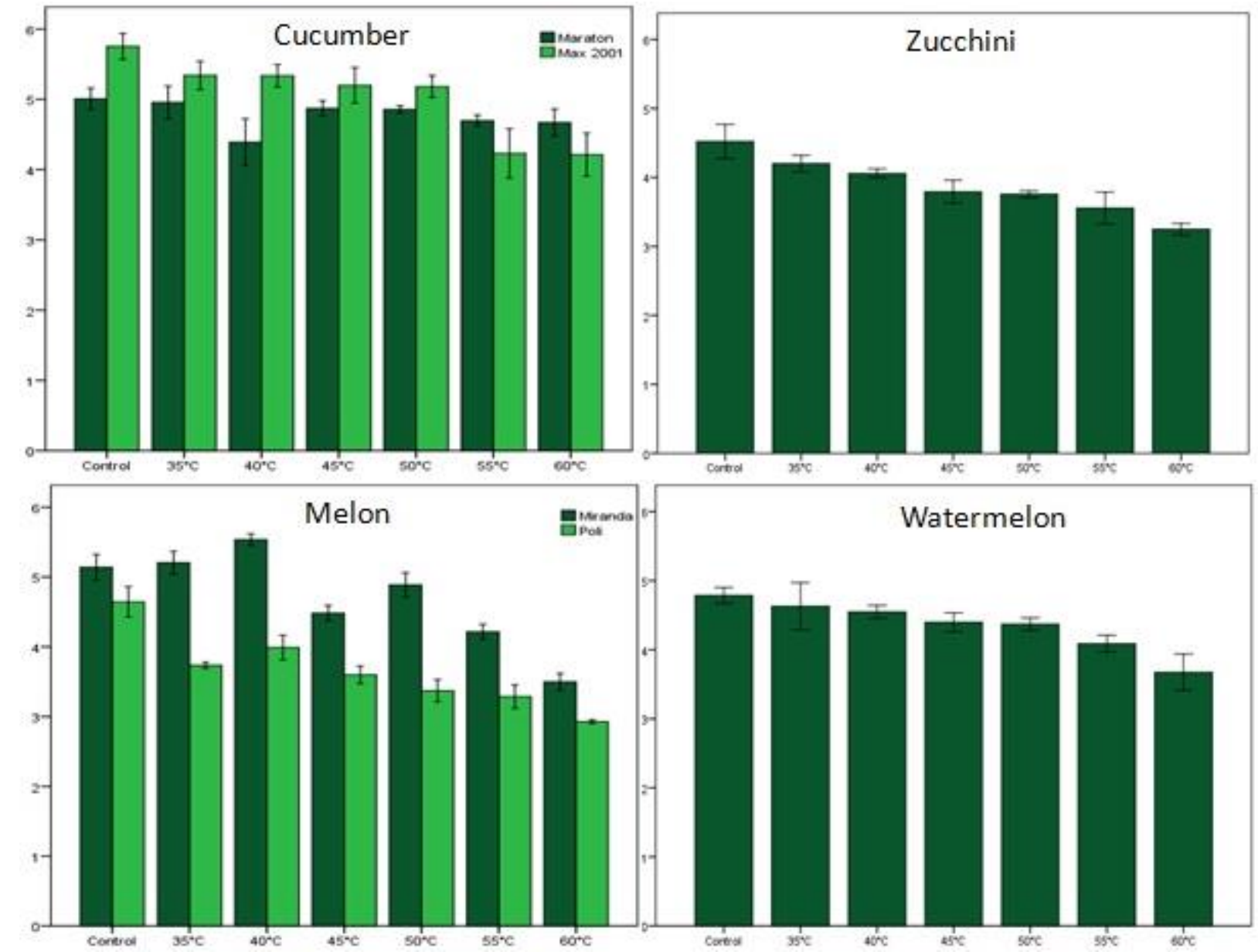

Figure 2. Effects of high temperature stress on total chlorophyll content ( $\mathrm{mg} \mathrm{g}^{-1} \mathrm{FW}$ ) of cucurbit plants. Vertical bars indicate \pm S.E. 


\begin{tabular}{|c|c|}
\hline & \\
\hline $\begin{array}{l}\text { Current Trends in Natural Sciences (on-line) } \\
\text { ISSN: 2284-953X } \\
\text { ISSN-L: 2284-9521 }\end{array}$ & $\begin{array}{r}\text { Current Trends in Natural Sciences (CD-Rom) } \\
\text { ISSN: 2284-9521 } \\
\text { ISSN-L: 2284-9521 }\end{array}$ \\
\hline
\end{tabular}

Leaf RWC of all cucurbit pants decreased gradually from the control to the highest temperature $\left(60^{\circ} \mathrm{C}\right)$ (Figure 3 and Table 1). In cucumber plants, the highest RWC (93\% in cv. Maraton and 75\% in cv. Max 2001) was determined at control, while the lowest one (75\% in cv. Maraton and $51 \%$ in cv. Max 2001) was at $60^{\circ} \mathrm{C}$ in both cultivars. Leaf RWC of cv. Maraton was higher than in cv. Max 2001 in all temperatures except at $60^{\circ} \mathrm{C}$. In zucchini, RWC was decreased slightly until $55^{\circ} \mathrm{C}$, but it was decreased at $60^{\circ} \mathrm{C}$ significantly. Leaf RWC was decreased depending on the temperatures in both cultivars of melon plants. However, RWC of cv. Poli was higher than in cv. Miranda at all temperatures. While RWC was decreased significantly at $35^{\circ} \mathrm{C}$, after this temperature it was not changed significantly in watermelon. However, loss of turgidity showed an opposite trend to RWC in all cucurbit plants and it was increased as the temperature increased (Table 1).
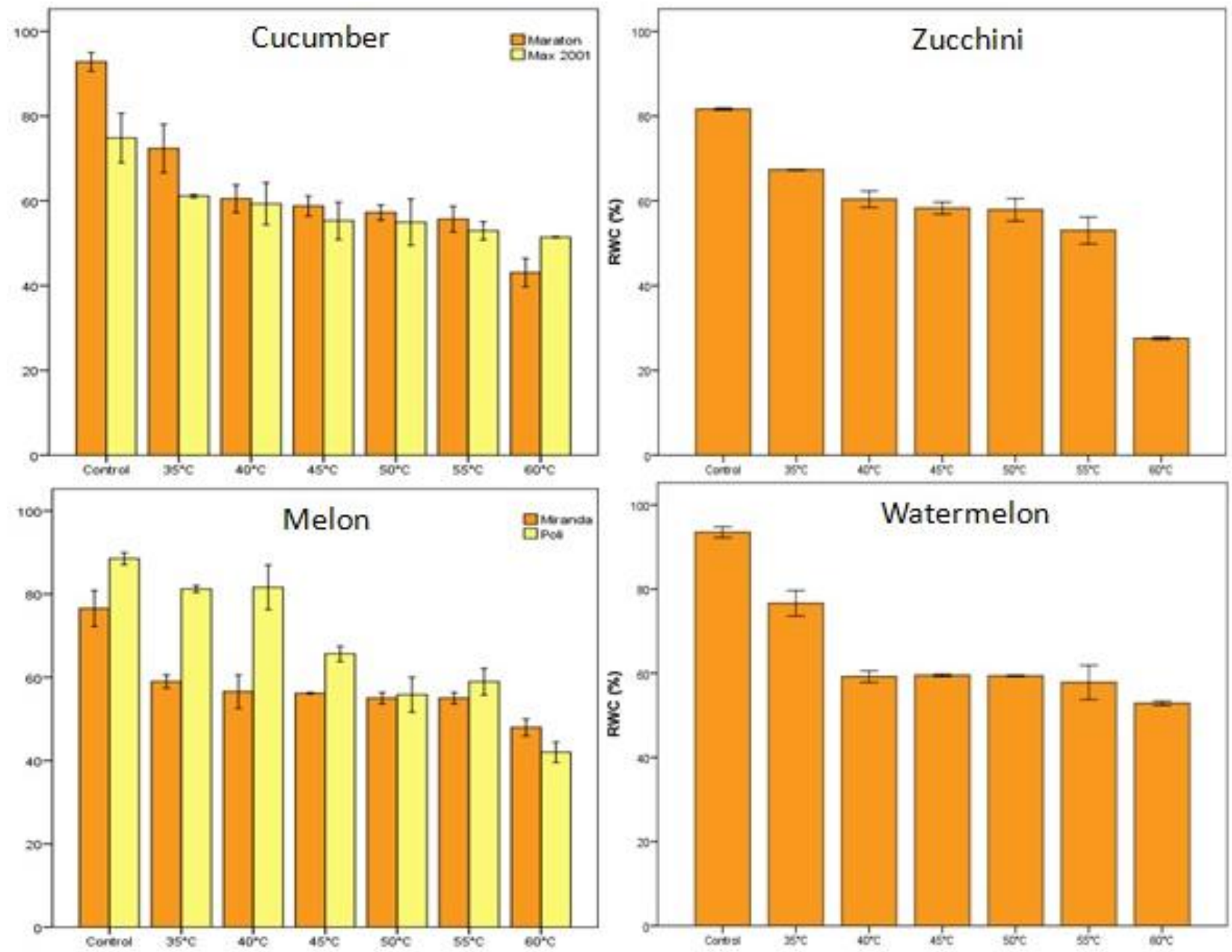

Figure 3. Effects of high temperature stress on RWC (\%) of cucurbit plants. Vertical bars indicate \pm S.E.

Relative water content is used to determine the water status of plants (Yamasaki and Dillenburg, 1999). High temperatures cause increases in transpiration, and this change leads to a reduction in the leaf RWC and the loss of turgidity (Cansev, 2012). In this study, the linear decrease in leaf RWC and linear increase in leaf loss of turgidity were detected in all cucurbit plants in response to 


\section{Current Trends in Natural Sciences}

Vol. 10, Issue 19, pp. 235-245, 2021

https://doi.org/10.47068/ctns.2021.v10i19.031

Current Trends in Natural Sciences (on-line)

ISSN: 2284-953X

Current Trends in Natural Sciences (CD-Rom)

ISSN: 2284-9521

ISSN-L: 2284-9521

ISSN-L: 2284-9521

high temperatures. The results obtained from the previous studies with turfgrass, mungbean and tomato, were supported our results (Xu et al., 2006; Kumar et al., 2011; Turhan et al., 2014).

In cucumber plants, TSP content was showed fluctuations due to high temperatures (Table 1). The highest (23.6 mg prot. $\mathrm{g}^{-1} \mathrm{FW}$ ) and lowest (9.0 mg prot. $\left.\mathrm{g}^{-1} \mathrm{FW}\right) \mathrm{TSP}$ content was obtained in cv. Max 2001 at $35^{\circ} \mathrm{C}$ and at $60^{\circ} \mathrm{C}$ respectively. TSP content of zucchini was not changed with the high temperature applications. While the amount of TSP in melon did not changed until $50^{\circ} \mathrm{C}$, then it was decreased significantly at $60^{\circ} \mathrm{C}$. In terms of TSP amount, a situation similar to cucumber was observed in watermelon.

Effects of high temperature stress on SDS-PAGE protein profiles of cucurbit plants were shown in Figure 4. The protein bands were determined ranging in size between about 84.1 and $16.4 \mathrm{kDa}$ in cucumber, 121.3 and $6.5 \mathrm{kDa}$ in zucchini, 158.2 and $21.4 \mathrm{kDa}$ in melon and 211.0 and $18.9 \mathrm{kDa}$ in watermelon, which densities sinking with high temperatures. According to SDS-PAGE results, a protein band that could be responsible for high temperature stress could not be determined in cucurbit plants.

Proteins in general are very sensitive to any change in temperature. Heat stress has a negative effect on protein structure and activity (Hasanuzzaman et al., 2013). It is known that high temperatures cause denaturing proteins by causing misfolding (Haq et al, 2019; Osman et al., 2020).

Cucumber

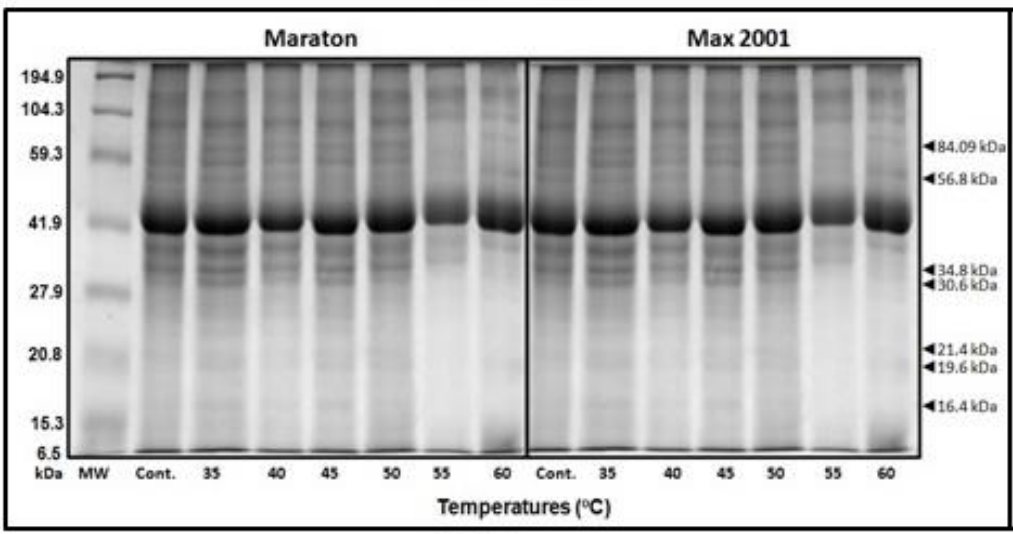

Melon

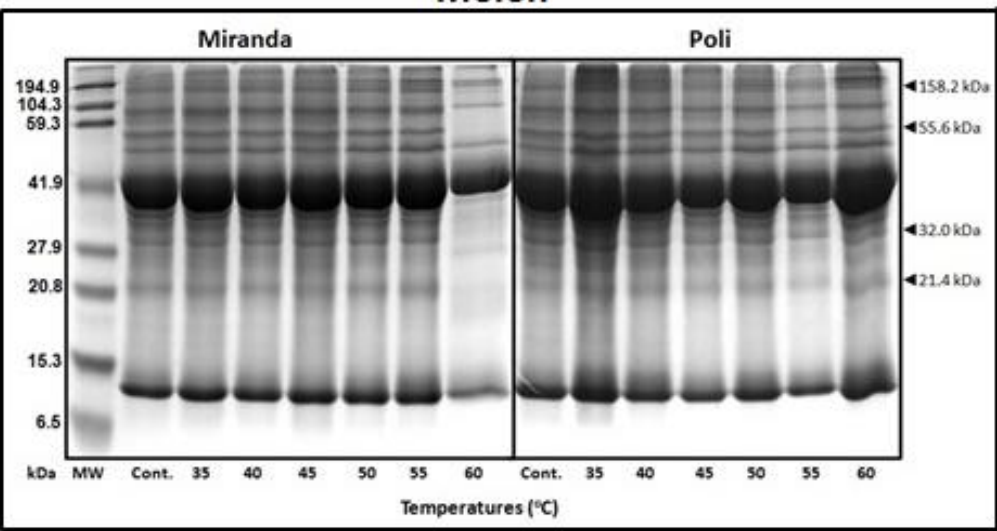

Zucchini

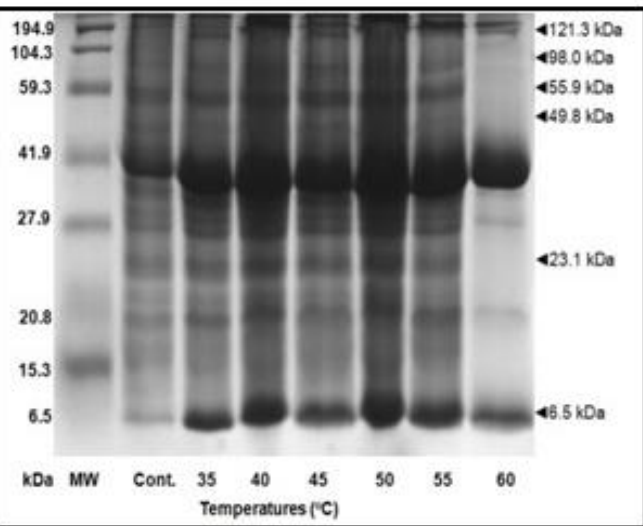

Watermelon

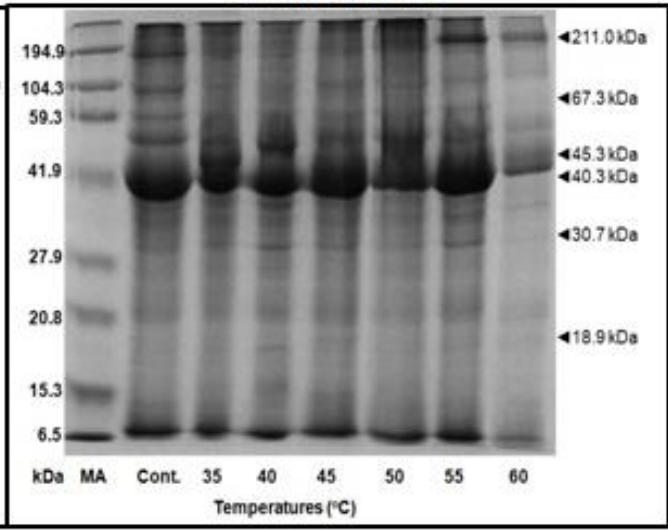

Figure 4. Effects of high temperature stress on SDS-PAGE protein profiles of cucurbit plants. In each lane, $10 \mu \mathrm{g}$ of protein was loaded. Molecular weight markers (MW) and the molecular mass $(k D a)$ are shown on the left side. The arrow on the right mark indicates the position of proteins that changed under heat stress 


\section{Current Trends in Natural Sciences}

Vol. 10, Issue 19, pp. 235-245, 2021

https://doi.org/10.47068/ctns.2021.v10i19.031

Current Trends in Natural Sciences (on-line)

ISSN: 2284-953X

Current Trends in Natural Sciences (CD-Rom)

ISSN: 2284-9521

ISSN-L: 2284-9521

ISSN-L: 2284-9521

Table 1. Results of variance analysis (ANOVA) of heat stress on ion leakage, total chlorophyll content, o relative water content (RWC), loss of turgidity and total soluble protein content (TSP) of cucurbit plants

\begin{tabular}{|c|c|c|c|c|c|c|c|}
\hline Species & Cvs. & Temp. & $\begin{array}{c}\text { Ion leakage } \\
(\%)\end{array}$ & $\begin{array}{c}\text { Total } \\
\text { Chlorophyll } \\
\left(\mathrm{mg} \mathrm{g}^{-1} \mathrm{FW}\right)\end{array}$ & RWC (\%) & $\begin{array}{c}\text { Loss of } \\
\text { Turgidity }(\%)\end{array}$ & $\begin{array}{c}\text { TSP } \\
\text { (mg prot g-1 } \\
\text { FW ) }\end{array}$ \\
\hline \multirow{14}{*}{ Cucumber } & Maraton & \multirow[t]{2}{*}{ Control } & $26.64 \pm 2.07$ & $5.01 \pm 0.15$ & $92.79 \pm 2.24$ & $7.01 \pm 0.58$ & $18.20 \pm 0.68$ \\
\hline & Max 2001 & & $23.18 \pm 1.24$ & $5.75 \pm 0.19$ & $74.83 \pm 5.85$ & $26.34 \pm 1.97$ & $23.40 \pm 0.16$ \\
\hline & Maraton & \multirow[t]{2}{*}{$35^{\circ} \mathrm{C}$} & $28.73 \pm 0.84$ & $4.96 \pm 0.23$ & $72.37 \pm 5.72$ & $25.88 \pm 1.39$ & $20.80 \pm 0.23$ \\
\hline & Max 2001 & & $27.21 \pm 0.54$ & $5.34 \pm 0.20$ & $61.14 \pm 0.37$ & $32.84 \pm 0.48$ & $23.60 \pm 0.38$ \\
\hline & Maraton & \multirow[t]{2}{*}{$40^{\circ} \mathrm{C}$} & $28.67 \pm 1.41$ & $4.39 \pm 0.33$ & $60.50 \pm 3.26$ & $33.70 \pm 3.02$ & $17.40 \pm 0.72$ \\
\hline & Max 2001 & & $30.99 \pm 1.14$ & $5.34 \pm 0.16$ & $59.31 \pm 4.96$ & $31.54 \pm 3.11$ & $22.50 \pm 0.44$ \\
\hline & Maraton & \multirow[t]{2}{*}{$45^{\circ} \mathrm{C}$} & $31.34 \pm 1.11$ & $4.87 \pm 0.11$ & $58.77 \pm 2.38$ & $35.80 \pm 2.42$ & $21.40 \pm 0.65$ \\
\hline & Max 2001 & & $36.18 \pm 1.53$ & $5.20 \pm 0.25$ & $55.29 \pm 4.43$ & $35.25 \pm 2.78$ & $17.60 \pm 0.82$ \\
\hline & Maraton & \multirow[t]{2}{*}{$50^{\circ} \mathrm{C}$} & $34.26 \pm 0.93$ & $4.86 \pm 0.05$ & $57.24 \pm 1.81$ & $36.75 \pm 1.74$ & $19.40 \pm 0.68$ \\
\hline & Max 2001 & & $36.18 \pm 2.09$ & $5.18 \pm 0.16$ & $54.95 \pm 5.50$ & $33.60 \pm 0.40$ & $20.90 \pm 0.73$ \\
\hline & Maraton & \multirow[t]{2}{*}{$55^{\circ} \mathrm{C}$} & $42.07 \pm 0.62$ & $4.70 \pm 0.08$ & $55.70 \pm 3.03$ & $38.74 \pm 2.84$ & $12.20 \pm 0.72$ \\
\hline & Max 2001 & & $51.93 \pm 3.52$ & $4.23 \pm 0.35$ & $52.93 \pm 2.14$ & $40.39 \pm 1.85$ & $16.70 \pm 0.78$ \\
\hline & Maraton & \multirow[t]{2}{*}{$60^{\circ} \mathrm{C}$} & $80.55 \pm 2.22$ & $4.67 \pm 0.19$ & $43.06 \pm 3.33$ & $49.88 \pm 3.47$ & $13.00 \pm 0.37$ \\
\hline & Max 2001 & & $80.83 \pm 2.05$ & $4.21 \pm 0.31$ & $51.42 \pm 0.12$ & $40.94 \pm 1.00$ & $9.00 \pm 0.46$ \\
\hline $\mathrm{Cv}$ & & & $*$ & $*$ & $\mathrm{~ns}$ & ns & $*$ \\
\hline Temp. & & & $*$ & $*$ & $*$ & $*$ & $*$ \\
\hline $\mathrm{Cv} * \mathrm{Temp}$ & & & * & * & ns & $*$ & * \\
\hline \multirow{7}{*}{ Zucchini } & \multirow{7}{*}{ Asma } & Control & $28.60 \pm 0.65$ & $4.52 \pm 0.25$ & $81.63 \pm 0.19$ & $16.48 \pm 0.15$ & $12.02 \pm 0.15$ \\
\hline & & $35^{\circ} \mathrm{C}$ & $38.65 \pm 0.41$ & $4.20 \pm 0.12$ & $67.32 \pm 0.12$ & $29.96 \pm 0.20$ & $12.66 \pm 0.18$ \\
\hline & & $40^{\circ} \mathrm{C}$ & $50.36 \pm 0.90$ & $4.06 \pm 0.07$ & $60.38 \pm 1.95$ & $35.49 \pm 1.69$ & $12.61 \pm 0.09$ \\
\hline & & $45^{\circ} \mathrm{C}$ & $60.16 \pm 4.45$ & $3.79 \pm 0.17$ & $58.26 \pm 1.43$ & $38.45 \pm 1.33$ & $12.56 \pm 0.26$ \\
\hline & & $50^{\circ} \mathrm{C}$ & $71.01 \pm 2.52$ & $3.76 \pm 0.05$ & $57.88 \pm 2.66$ & $38.66 \pm 2.83$ & $12.35 \pm 0.26$ \\
\hline & & $55^{\circ} \mathrm{C}$ & $78.39 \pm 3.34$ & $3.56 \pm 0.23$ & $52.99 \pm 3.19$ & $43.37 \pm 2.94$ & $12.24 \pm 0.31$ \\
\hline & & $60^{\circ} \mathrm{C}$ & $83.60 \pm 0.54$ & $3.25 \pm 0.08$ & $27.55 \pm 0.25$ & $65.55 \pm 0.15$ & $12.55 \pm 0.48$ \\
\hline Temp. & & & $*$ & $*$ & $*$ & $*$ & ns \\
\hline \multirow{14}{*}{ Melon } & Miranda & \multirow[t]{2}{*}{ Control } & $24.53 \pm 0.26$ & $5.52 \pm 0.18$ & $76.56 \pm 4.30$ & $26.18 \pm 0.06$ & $34.20 \pm 0.15$ \\
\hline & Poli & & $14.67 \pm 0.33$ & $4.91 \pm 0.22$ & $88.52 \pm 1.44$ & $11.79 \pm 0.81$ & $36.54 \pm 0.42$ \\
\hline & Miranda & \multirow[t]{2}{*}{$35^{\circ} \mathrm{C}$} & $26.91 \pm 1.54$ & $4.95 \pm 0.16$ & $59.01 \pm 1.59$ & $37.64 \pm 0.97$ & $34.41 \pm 0.26$ \\
\hline & Poli & & $16.72 \pm 0.81$ & $3.73 \pm 0.05$ & $81.23 \pm 0.80$ & $17.05 \pm 0.57$ & $35.74 \pm 0.14$ \\
\hline & Miranda & \multirow[t]{2}{*}{$40^{\circ} \mathrm{C}$} & $27.49 \pm 1.38$ & $5.53 \pm 0.09$ & $56.56 \pm 4.05$ & $36.09 \pm 2.27$ & $33.54 \pm 0.25$ \\
\hline & Poli & & $17.26 \pm 1.14$ & $3.67 \pm 0.18$ & $81.60 \pm 5.39$ & $25.87 \pm 2.29$ & $34.27 \pm 0.06$ \\
\hline & Miranda & \multirow[t]{2}{*}{$45^{\circ} \mathrm{C}$} & $31.67 \pm 2.61$ & $4.87 \pm 0.11$ & $56.20 \pm 0.68$ & $38.40 \pm 0.92$ & $32.89 \pm 0.11$ \\
\hline & Poli & & $17.89 \pm 1.22$ & $3.60 \pm 0.13$ & $65.66 \pm 1.85$ & $30.84 \pm 1.77$ & $33.67 \pm 0.15$ \\
\hline & Miranda & \multirow[t]{2}{*}{$50^{\circ} \mathrm{C}$} & $41.71 \pm 3.89$ & $4.62 \pm 0.18$ & $55.00 \pm 1.35$ & $40.66 \pm 1.02$ & $32.77 \pm 0.18$ \\
\hline & Poli & & $19.59 \pm 0.38$ & $3.37 \pm 0.16$ & $55.83 \pm 4.20$ & $31.89 \pm 1.13$ & $33.79 \pm 0.31$ \\
\hline & Miranda & \multirow[t]{2}{*}{$55^{\circ} \mathrm{C}$} & $66.50 \pm 1.62$ & $4.22 \pm 0.11$ & $55.00 \pm 1.35$ & $40.66 \pm 1.02$ & $30.73 \pm 0.17$ \\
\hline & Poli & & $55.00 \pm 0.76$ & $3.29 \pm 0.17$ & $58.96 \pm 3.22$ & $32.28 \pm 2.36$ & $34.99 \pm 0.61$ \\
\hline & Miranda & \multirow[t]{2}{*}{$60^{\circ} \mathrm{C}$} & $71.73 \pm 1.80$ & $3.50 \pm 0.12$ & $47.38 \pm 2.04$ & $48.15 \pm 2.09$ & $16.16 \pm 0.03$ \\
\hline & Poli & & $66.30 \pm 1.28$ & $2.93 \pm 0.03$ & $42.02 \pm 2.47$ & $52.65 \pm 2.32$ & $22.70 \pm 0.13$ \\
\hline Cv. & & & $*$ & $*$ & $*$ & $*$ & $*$ \\
\hline Temp. & & & $*$ & $*$ & $*$ & $*$ & $*$ \\
\hline \multirow{7}{*}{ Watermelon } & \multirow{8}{*}{$\begin{array}{l}\text { Crimson } \\
\text { Tide }\end{array}$} & Control & $13.74 \pm 0.25$ & $4.79 \pm 0.12$ & $93.50 \pm 1.28$ & $4.64 \pm 0.36$ & $25.85 \pm 0.11$ \\
\hline & & $35^{\circ} \mathrm{C}$ & $23.79 \pm 1.40$ & $4.63 \pm 0.34$ & $76.62 \pm 3.03$ & $20.96 \pm 1.57$ & $24.49 \pm 0.52$ \\
\hline & & $40^{\circ} \mathrm{C}$ & $27.28 \pm 1.81$ & $4.55 \pm 0.09$ & $59.19 \pm 1.40$ & $36.70 \pm 1.35$ & $26.72 \pm 0.31$ \\
\hline & & $45^{\circ} \mathrm{C}$ & $29.82 \pm 1.06$ & $4.40 \pm 0.14$ & $59.50 \pm 0.31$ & $37.63 \pm 0.79$ & $25.11 \pm 0.10$ \\
\hline & & $50^{\circ} \mathrm{C}$ & $43.82 \pm 0.41$ & $4.37 \pm 0.09$ & $59.36 \pm 0.17$ & $37.82 \pm 0.42$ & $36.02 \pm 0.16$ \\
\hline & & $55^{\circ} \mathrm{C}$ & $60.89 \pm 1.34$ & $4.09 \pm 0.12$ & $57.82 \pm 4.07$ & $42.64 \pm 0.36$ & $23.45 \pm 0.77$ \\
\hline & & $60^{\circ} \mathrm{C}$ & $71.87 \pm 1.51$ & $3.67 \pm 0.26$ & $52.87 \pm 0.54$ & $42.90 \pm 0.52$ & $17.68 \pm 0.11$ \\
\hline Temp. & & & $*$ & $*$ & $*$ & $*$ & $*$ \\
\hline
\end{tabular}

${ }^{\mathrm{ns}}$ Non significant

* Significant at 0,05 
The protein content of Trigonella was significantly decreased by $27.8 \%$ at $35^{\circ} \mathrm{C}$ and $69.4 \%$ at $40^{\circ} \mathrm{C}$ respectively comparing to control samples (Osman et al., 2020). Yadav et al. (2017) found that high temperature stress led to disruption of cellular membranes by increasing cell membrane injury, lipid peroxidation and $\mathrm{H}_{2} \mathrm{O}_{2}$ contents. This led to decrease in total chlorophyll and soluble proteins.

It was determined that while the TSP content decreased, the total amino acid and proline content increased in mulberry leaves exposed to $40^{\circ} \mathrm{C}$ for 2,4 and 6 hours (Chaitanya et al., 2001). New proteins are synthesized in response to high temperature and there are decreases and almost complete disappearance of proteins due to high temperatures in strawberry plants (Ergin et al., 2016). Turhan et al. (2015) detected bands ranging in size from 7-54 kDa in pepper plants under high temperature stress conditions and pointed out that $40 \mathrm{kDa}$ HSP protein may be associated with tolerance to high temperature. In this study, it has been found that TSP content does not play an important role in tolerating high temperatures in cucurbits. Additionally, protein band $\mathrm{s}$ with molecular weights ranging from 6.5 to $211 \mathrm{kDa}$ were detected in cucurbit plants, and it was determined that the synthesis of these proteins was lost at high temperatures

\section{CONCLUSIONS}

Both cultivars of cucumber and watermelon can tolerate high temperatures up to $50^{\circ} \mathrm{C}$ according to ion leakage results. Considering the result of ion leakage and loss of turgidity, zucchini has a low tolerance to high temperatures. In terms of ion leakage, RWC, loss of turgidity and TSP, cv. Poli can tolerate high temperatures up to $50^{\circ} \mathrm{C}$, while the $\mathrm{cv}$. Miranda has a low tolerance among melon cultivars. It has been determined that the amount of TSP is not associated with heat tolerance in cucurbit plants. There is no protein band was determined as responsible for heat stress tolerance in cucurbit plants. In order to better understand the temperature stress tolerance of cucurbit plants, further studies on the molecular behavior of these plants are required.

\section{REFERENCES}

Almeselmani, M., Deshmukh, P.S., Sairam, R.K., Kushwaha, S.R. Singh, T.P. (2006). Protective role of antioxidant enzymes under high temperature stress. Plant Sience, 171, 382-388.

Arora, R., Pitchay, D.S., Bearce, B.C. (1998). Waterstress-induced heat tolerance in geranium leaf tissues: A possible linkage through stress proteins. Physiologica Plantarum, 103, 24-34.

Arora, R., Wisniewski, M.E., Scorza, R. (1992). Cold acclimation ingenetically related (sibling) deciduous and evergreen peach (Prunus persica L. Batsch). I. Seasonal changes in cold hardiness and polypeptides of bark and xylem tissues. Plant Physiol, 99, 1562-1568.

Balal, R.M., Shahid, M.A., Javaid, M.M., Iqbal, Z., Anjum, M.A., Garcia-Sanchez, F., Mattson, N.S. (2016). The role of selenium in amelioration of heat-induced oxidative damage in cucumber under high temperature stress. Acta Physiol Plant, 38, 1-14.

Barrs, H.D., Weatherley, P.E. (1962). A re-examination of the relative turgidity technique for estimating water deficit in leaves. Australian Journal of Biological Sciences, 15, 413-428.

Bita, C.E., Gerats, T. (2013). Plant tolerance to high temperature in a changing environment: scientific fundamentals and production of heat stress-tolerant crops. Frontiers in Plant Science, 4(273), 1-18.

Bradford, M.M. (1976). A rapid and sensitive method for quantitation of microgram quantities of protein utilizing the principle of protein dye binding. Analytical Biochemistry, 72, 248-254.

Bray, E.A., Bailey-Serres, J., Weretilnyk, E. (2000). Responses to abiotic stresses. In W. Gruissem, B.B. Buchannan, R.L. Jones, eds, Biochemistry and Molecular Biology of Plants. (pp. 1158-1203). Rockville: American Society of Plant Physiologists, Rockville.

Cansev, A. (2012). Physiological effects of high temperature treatments on leaves of olive cv. 'Gemlik'. Plant Arch 12, 521-525. 


\section{Current Trends in Natural Sciences}

Vol. 10, Issue 19, pp. 235-245, 2021

https://doi.org/10.47068/ctns.2021.v10i19.031

Current Trends in Natural Sciences (on-line)

ISSN: 2284-953X

Current Trends in Natural Sciences (CD-Rom)

ISSN: 2284-9521

ISSN-L: 2284-9521

ISSN-L: 2284-9521

Chaitanya, K.V, Sundar, D., Masilamani, S., Ramachandra Reddy, A. (2001). Variation in heat stress-induced antioxidant enzyme activities among three mulberry cultivars. Plant Growth Regulation, 00, 1-6.

Christiansen, M.N. (1978). The physiology of plant tolerance to temperature extremes. In G.A. Jung, eds, Crop Tolerance to Suboptimal Land Conditions (pp. 173-191). Wisconsin, American Soc. Agronomy, Wisconsin.

Correia, B., Valledor, L., Meijon, M., Rodriguez, J.L., Dias, M.C., Santos, C., Canal, M.J., Rodriguez, R., Pinto, G. (2014). Is the interplay between epigenetic markers related to the acclimation of cork oak plants to high temperatures?. Plos One, 8(1), e53543.

Deshmukh, P.S., Sairam, R.K., Shukla, D.S. (1991). Measurement of ion leakage as a screening technique for drought resistance in wheat genotypes. Indian J.Plant Physiol. 34, 89-901.

Dhanda, S.S., Sethi, G.S. (2002). Tolerance to drought stress among selected Indian wheat cultivars. The Journal of Agricultural Science, 139(3), 319-326.

Dutta, S., Mohanty, S., Tripathy, B.C. (2009). Role of temperature stress on chloroplast biogenesis and protein import in pea. Plant Physiol, 150(2), 1050-1061.

Efeoglu, B., Terzioglu, S. (2009). Photosynthetic responses of two wheat varieties to high temperature, Eur. Asia J. BioSci. 3(1), 97-106.

Ergin, S., Gulen, H., Kesici, M., Turhan, Ipek, A., Koksal, N. (2016). Effects of high temperature stress on enzymatic and nonenzymatic antioxidants and proteins in strawberry plants. Turkish Journal of Agriculture and Forestry, 40, 908-917.

Gitelson, A.A., Merzlyak, M.N. (2003). Relationships between leaf chlorophyll content and spectral reflectance and algorithms for non-destructive chlorophyll assessment in higher plant leaves. J. Plant Physiol. 160(3), 271-282.

Guy, C. (1999). Molecular responses of plants to cold shock and cold acclimation. J. Mol. Microbiol. Biotechnol. 1, 231-242.

Haq, S., Khan, A., Ali, M., Khattak, A.M., Gai, W.X., Zhang, H.X., Wei, A.M., Gong, Z.H. (2019). Heat shock proteins: dynamic biomolecules to counter plant biotic and abiotic stresses. International journal of molecular sciences, 20(5321), 1-31.

Hasanuzzaman, M., Nahar, K., Alam, M.M., Roychowdhury, R., Fujita, M. (2013). Physiological, biochemical, and molecular mechanisms of heat stress tolerance in plants. Int. J. Mol. Sci. 14(5), 9643-9684.

Hou, W. Sun A.H., Chen, H.L., Yang, F.S., Pan, J.L., Guan, M.Y. (2016). Effects of chilling and high temperatures on photosynthesis and chlorophyll fluorescence in leaves of watermelon seedlings. Biologia Plantarum, 60(1), 148154.

Ilik , P., Spundova, M., Sicner, M., Melkovicova, H., Kucerova, Z., Krchnak, P., Furst, T., Vecerova, K., Panzarova, K., Benediktyova, Z., Trtilek, M. (2018). Estimating heat tolerance of plants by ion leakage: a new method based on gradual heating. New Phytologist 218, 1278-1287.

Kumar, S., Kaur, R., Kaur, N., Bhandhari, K., Kaushal, N., Gupta, K., Bains, T.S., Nayyar, H. (2011). Heat-stress induced inhibition in growth and chlorosis in mungbean (Phaseolus aureus Roxb.) is partly mitigated by ascorbic acid application and is related to reduction in oxidative stress. Acta Physiologiae Plantarum, 33(6), 2091-2101.

Levitt, J. (1980). Responses of plants to environmental stresses. (Vol. 1, pp. 347-391). New York: Academic Press, New York.

Lin, D.D., Zhang, G.F., Yu, J.B., Feng, J. (2011). Analyses of photosynthetic pigment content and chlorophyll fluorescence parameter in leaves of different clones of Cinnamomum camphora. J Plant Resour Environ, 20(3), 56-61.

Liu, J., Xie, X., Du, J., Sun, J., Bai, X. (2008). Effects of simultaneous drought and heat stress on Kentucky bluegrass. Scientia Horticulturae, 115(2), 190-195.

Mathis, J.N., Burkey, K.O. (1989). Light intensity regulates the accumulation of the major light-harvesting chlorophyllprotein in greening seedlings. Plant Physiol 90(2), 560-566.

Mathur, S., Agrawal, D., Jajoo, A. (2014). Photosynthesis: Response to high temperature stress. Journal of Photochemistry and Photobiology B: Biology 137, 116-126.

Moran, R., Porath, D. (1980). Chlorophyll determination in intact tissues using N,N dimethylformamide. Plant Physiology, 65, 478-479.

Osman, M., El-Feky, S., Seliem, H., Abo-Hamad, S. (2020). Physiological impact of putrescine on Trigonella foenumgraecum L. growing under temperature stress. Food Sci. Technol, DOI: https://doi.org/10.1590/fst.13820. 


\section{Current Trends in Natural Sciences}

Vol. 10, Issue 19, pp. 235-245, 2021

https://doi.org/10.47068/ctns.2021.v10i19.031

Current Trends in Natural Sciences (on-line)

ISSN: 2284-953X

Current Trends in Natural Sciences (CD-Rom)

ISSN: 2284-9521

ISSN-L: 2284-9521

ISSN-L: 2284-9521

Palma, F., Carvajal, F., Lluch, C., Jamilena, M., Garrido, D. (2014). Changes in carbohydrate content in zucchini fruit (Cucurbita pepo L.) under low temperature stress. Plant Science 217(218), 78- 86.

Pinero, M.C., Otalora, G., Collado, J., Lopez-Marin, J., Amor, F.M. (2021). Foliar application of putrescine before a short-term heat stress improves the quality of melon fruits (Cucumis melo L.). Journal of the Science of Food and Agriculture, 101, 1428-1435.

Pucciariello, C., Banti, V., Perata, P. (2012). ROS signaling as common element in low oxygen and heat stresses. Plant Physiol Biochem 59, 3-10.

Ruelland, E., Zachowski, A. (2010). How plants sense temperature. Environ. Exp. Bot. 69, 225-232.

Sharma, P., Jha, A.B., Dubey, R.S., Pessarakli, M. (2012). Reactive oxygen species, oxidative damage, and antioxidative defense mechanism in plants under stressful conditions. J Bot 10, 1-26.

Shen, S., Jing, Y., Kuang, T. (2003). Proteomics approach to identify wound-response related proteins from rice leaf sheath. Proteomics, 3(4), 527-535.

Shukla, P.R., Skea, J., Slade, R. (2019). Special report: Special report on climate change and land (Technical summary), Retrieved May 21, 2021, from http://www.ipcc.ch/srccl/chapter/technical-summary/

Silva, R.C.B., Araujo, M.N, Ornellas, F.L.S., Dantas, B.F. (2018). Thermal stress and physiological changes in watermelon seeds. Pesq. Agropec. Trop, 48(1), 66-74.

Suzuki, N., Mittler, R. (2006). Reactive oxygen species and temperature stresses: a delicate balance between signaling and destruction. Physiol Plant, 126, 45-51.

Suzuki, N., Koussevitzky, S., Mittler, R., Miller, G. (2012). ROS and redox signalling in the response of plants to abiotic stress. Plant, Cell and Environment, 35, 259-270.

Szymanskaa, R., Slesakb, I., Orzechowskaa, A., Krukc, J. (2017). Physiological and biochemical responses to high light and temperature stress in plants. Environmental and Experimental Botany, 139, 165-177.

Turhan, E., Aydogan, C., Ergin, S, Ozturk, N. (2014). Variation in heat stress-induced some physiological changes and peroxidase activities among three tomato (Lycopersicon esculentum Mill.) cultivars. Turkish Journal of Agricultural and Natural Sciences, 2, 1492-1498.

Turhan, E., Aydogan, C., Ergin, S., Ozturk, N. (2015). Proteins in pepper plants (Capsicum annuum L.) under heat stress. Journal of Biotechnology, 208, 31.

Wang, J., Zhang, H., Allen, R.D. (1999). Overexpression of an Arabidopsis peroxisomal ascorbate peroxidases gene in tobacco increases protection against oxidative stress. Plant Cell Physiol. 140 (6), 7225-732.

Weis, E., Berry, J.A. (1988). Plants and high temperature stress. Symp Soc Exp Biol 42, 329-346.

$\mathrm{Xu}, \mathrm{S}$., Li, J., Zhang, X., Wei, H., Cui, L. (2006). Effects of heat acclimation pretreatment on changes of membrane lipid peroxidation, antioxidant metabolites, and ultrastructure of chloroplasts in two cool-season turfgrass species under heat stress. Environ Expt Bot 56, 274-285.

Yadav, S., Pavan, K., Tiwari, Y., Jainender, J., Jyothi, N. (2017). Exogenous application of bio-regulators for alleviation of heat stress in seedlings of maize. Journal of Agricultural Research, 2(3), 000137.

Yamasaki, S., Dillenburg L.R. (1999). Measurements of leaf relative water content in Araucaria angustifolia. Revista Brasilleira de Fisiologia Vegetal, 11(2), 69-75.

Zhou, H., Guo, S., An, Y., Shan, X., Wang, Y., Shu, S., Sun, J. (2016). Exogenous spermidine delays chlorophyll metabolism in cucumber leaves (Cucumis sativus L.) under high temperature stress. Acta Physiol Plant, 38(224), 1-12. 